\title{
Antysemityzm jako element konstytutywny polskiego habitusu
}

Romana Kolarzowa

TEKSTY DRUGIE 2018, NR 3, S. 227-240

DOI: $10.18318 /$ td.2018.3.15

D ystynkcja antyjudaizm/antysemityzm wywodzi się z rozważań Hannah Arendt. W Korzeniach totalitaryzmu autorka pisze: „antysemityzm, świecka ideologia XX stulecia, która z nazwy, chociaż nie z argumentacji, była nieznana do lat 70. [XIX w. - przypomnienie i podkreślenie - R.K.] i religijna nienawiść do Żydów to oczywiście [...] nie to samo" (1951; 1993, s. 33) ${ }^{1}$. Pogląd ten, znacznie później, podzielił Jacob $\mathrm{Katz}^{2}$. Dlaczego nie jest możliwe utrzymanie, że nie istnieje związek między „świeckim” antysemityzmem a „religijną nienawiścią do Żydów”, bardzo obszernie przedstawił G.I. Langmuir ${ }^{3}$. Kluczowa jest konstatacja,

1 H. Arendt Korzenie totalitaryzmu, przeł. D. Grinberg, M. Szawiel, Wydawnictwa Akademickie i Profesjonalne, Warszawa 2011, s. 33.

2 Por. J. Katz Emancipation and Assimilation: Studies in Modern Jewish History, Gregg, Westmead 1980, s. 316-320.

3 G.I. Langmuir History, Religion, and Antisemitism, University of California Press, Berkeley 1990. Pokrewny punkt widzenia proponuje J. Tokarska-Bakir Legendy o krwi. Antropologia przesq̨du, W.A.B., Warszawa 2008, cz. II. Współczesne narracje o krwi, zwł. rozdz. 7, cz. 4, s. $612-636$.
Romana Kolarzowa dr hab., antropolożka kultury, zajmuje się kulturą żydowską i zagadnieniami kształtowania tożsamości i doświadczeń traumatycznych. Pracuje w Instytucie Filozofii Uniwersytetu Rzeszowskiego. Ostatnio opublikowała Ciężkie sny na "poduszce pani Marx."Ukryta euforia okupacyjnych przewłaszczeń w Polsce ("Teksty Drugie" nr 2, 2017) i W poszukiwaniu skazy. Migawki z procesu samowykluczenia (J. Hańderek, N. Kućma, Wykluczenia. Perspektywy ponowoczesności, 2017). 
że w wielowiekowej debacie teologicznej ${ }^{4}$ oraz w tym, co określa się jako spór religijny. „antyjudaizm” był stanowiskiem normatywnym, z wszystkimi tego kulturowymi konsekwencjami, z których najistotniejsze jest formowanie postawy wobec grupy postrzeganej jako przeciwnik ${ }^{5}$. Wydawałoby się, że wykazanie związku między wytworzonym w kulturze chrześcijańskiej wizerunkiem Żyda oraz ustanowionym w obrębie kultury zachodniej stanowiskiem normatywnym wobec tej grupy kulturowej a konceptami „świeckiego" antysemityzmu nie pozostawia wątpliwości, że ów antysemityzm, nie tylko świecki, ale też modernistyczny niewiele nowego tworzy, za to najwyraźniej in extenso wykorzystuje zastane wzorce kultury. Christhard Hoffmann widzi ten związek wprost jako transformację ideologiczną ${ }^{6}$.

W tej retorycznej skrupulatności wyraźne jest dążenie do ekspulsowania antysemityzmu na margines tego, co europejskie. Wzorem literatury kanonicznej (Arendt, Adorno), podejmującej problematykę Zagłady, nie traci aktualności tendencja, aby systematycznie dystansować się - w imieniu Europy - od ideologii fundującej Endlösung. Paradygmatyczny schemat wyznaczania tego dystansu opierał się na dychotomii kultury zachodniej i zbrodniczego obłędu nazizmu. Nie całkiem jestem przekonana, że ta dychotomia należy do zjawisk bezwiednie „samoustanawiających się”; w tym niedostatecznym przekonaniu utrzymuje mnie świadomość, że w spopularyzowanie tego schematu, wręcz w uczynienie go wzorcem dyskursu, zaangażowanych było tak wielu prominentnych intelektualistów, że prawdopodobieństwo niezadania sobie pytania elementarnego: skąd nazizm mianowicie, jest nader nikłe. Znacznie bardziej prawdopodobne wydaje się przypuszczenie, że tak elementarne, wręcz naiwne pytanie mogło konsekwentnie budzić opór. Nie tyle moralny czy choćby taki, jaki jest skutkiem doświadczeń traumatycznych (choć tych form oporu bynajmniej nie zamierzam lekceważyć), ale właśnie opór czysto intelektualny. Co więcej - ta kontrowersja może mieć charakter pozorny;

4 Zob. streszczenie tej debaty G.I. Langmuir History, Religion and Antisemitism, s. 9-35.

5 Antropologicznie najlepiej rzecz wyłożył J. Trachtenberg w: Diabeł i Żydzi: średniowieczna koncepcja Żyda a współczesny antysemityzm, przeł. R. Stiller, Uraeus, Gdynia 2011, wyd. 2.

6 Ch. Hoffmann Christliche Antijudaismus und modernen Antisemitismus; Christlicher Antijudaismus und Antisemitismus. Theologische und kirchliche programme Deutscher Christen, Hrsg. L. Siegele-Wenschkewitz, Haag und Herchen Ver., Frankfurt am Main 1994, s. 293-317. Warto też zwrócić uwagę na diagnozę i konkluzje przedstawione przez Shulamit Volkov; S. Volkov Antysemityzm jako kod kulturowy; B. Breysach (i in.) Ze sobq, obok siebie, przeciwko sobie. Polacy, Żydzi, Austriacy i Niemcy wXIXi na poczq̨tkuXX wieku, przeł. B. Hański, Znak, Kraków 1995, s. 7-41. 
a zarazem może pełnić bardzo pożądaną funkcję. Funkcja ta, gdyby chcieć wskazać jej związek z nauką, powinna być sama raczej przedmiotem krytycznej refleksji.

Standardowe bowiem zaprzeczanie temu antyżydowskiemu toposowi kultury europejskiej uzasadnia się tym, że nie można mówić o antysemityzmie przed XIX wiekiem dla dwóch przyczyn: 1. wcześniej nie występowało takie pojęcie; 2. przednowoczesna wrogość wobec Żydów nie miała charakteru „naukowego”, a w szczególności „rasowego”. Podkreśla się też, że nie należy mieszać „zjawisk nowych" z „historycznymi”, co wskazuje na dążenie do zerwania (możliwych) relacji między konkretnym „zjawiskiem nowym” a „zjawiskiem historycznym”, chociaż zarówno w naukach humanistycznych, jak i społecznych dąży się raczej do ustalania związków między „zjawiskami nowymi” a „historycznymi”. Zgadzam się z Sanderem L. Gilmanem, że to sumienne rozgraniczanie „postaw antysemickich jest przedsięwzięciem z gruntu fałszywym. Mówienie o chrześcijańskim antyjudaizmie, o antysemityzmie naukowym i ludowym oznacza jedynie badanie powierzchni retoryki, w którą oblekają się powszechne postawy wobec innego"7. Nie lekceważyłabym jednak wskazanego przez Gilmana „badania powierzchni retoryki”; raczej uznałabym je za symptom oporu wobec dopuszczenia hipotezy, że antysemityzm jest doskonale ugruntowanym toposem kultury.

Być może zatem i ten opór, który odnaleźć można nawet u autorów mających reputację postapokaliptycznych kontestatorów, należałoby zacząć traktować jako mutację toposu „pięknej i bestii” - niewinnej kultury, zniewolonej przez barbarzyńców. Giorgio Agamben, stawiając retoryczno-fundamentalne pytanie, co zostaje $z$ Auschwitz ${ }^{\mathbf{8}}$, po to, aby ustanowić cezurę w dziejach kultury zachodniej, wpisuje się w tę dychotomię. Jej przekroczeniem byłoby właśnie postawienie pytania, ską nazizm, a tym samym - skąd Auschwitz. Postawienie tego pytania wymaga jednak uznania, że i nazizm, i Auschwitz

7 S.L. Gilman Jewish Self-Hatred. Anti-Semitism and the Hidden Language of the /ews, Johns Hopkins University Press, Baltimore 1986, s. 98.

8 Tytuł III części projektu Homo sacer, przeł. S. Królak, Sic!, Warszawa 2008. Wnikliwą krytykę tej pracy przedstawił D. LaCapra Wobec wydarzeń granicznych. Sytuowanie Agambena. Historia w okresie przejściowym. Doświadczenie, tożsamość, teoria krytyczna, przeł. K. Bojarska, Universitas, Kraków 2009, s 185-246. Kluczowe są tu rozważania (s. 232-240) środków, jakimi można wytwarzać "szarą strefę", w której "wydaje się ponownie znosić rolę oprawców jako sprawców". V także przyp. 38 . 
do tej kultury należy genetycznie9; bo w tej kulturze antysemityzm jest częścią jej kodu ${ }^{10}$ czy też, w terminologii Bourdieu, elementem europejskiego habitusu. Takie uznanie wymaga długiej i wielopłaszczyznowej analizy tej przynależności. Dodajmy - analizy krytycznej, starającej się dostrzec związki między faktami dotąd skrzętnie pomijanymi bądź bagatelizowanymi jako lokalne i incydentalne. Przykładem takiego „analitycznego” stosunku do kulturowych źródeł Auschwitz jest traktowanie pewnego dokumentu, poprzedzającego ekspulsję Żydów z Hiszpanii. Nadzwyczaj w kwestii odnajdowania wpływów historycznych skrupulatny Agamben w tym wypadku zrezygnował jednak z erudycji. Dokument ten, dekret Limpieza de sangre, ma ogromne znaczenie formacyjne. Najpierw dlatego, że w epoce nowożytnej formułuje i definiuje pojęcie czystości krwi. Następnie dlatego, że przez ponadlokalne instytucje religijne, które ustaloną w tym dekrecie definicję oraz kryteria uznały za własne, stał się wzorcem europejskim ${ }^{11}$. Podtrzymywanie dychotomicznego obrazu niewinnej Europy, zniewolonej przez mroczne siły o bliżej nieokreślonej proweniencji wymaga ćwiczenia się w niedostrzeganiu pewnych charakterystycznych szczegółów. Na jeden z nich zwrócił uwagę Jonathan Littell: na stanowiskach dowódców jednostek do zadań specjalnych była nadreprezentacja prawników z dyplomami doktorskimi ${ }^{12}$. Czyli jednak nie tylko "męty społeczne” (jak głosiła „historia naiwna"), ale wychowankowie idealnej struktury oświeceniowej, jaką był humboldtowski uniwersytet. Joanna Tokarska-Bakir zwróciła uwagę na to, że dr von Aue, główny bohater Littella, jest kimś, z kim czytelnik może chcieć się identyfikować - kimś znajomym, o kim może stwierdzić, „,że podoba mu się ta blond bestia"13.

9 R. Radford Ruethers Faith and Fratricide: The Theological Roots of Anti-Semitism, r. The Philosophing of AntiJudaism, Seabury, New York, 1974, s. 95-116.

Trafna diagnoza S. Volkov w moim przekonaniu wykracza poza XVIII-XX wiek. W XVIII wieku ten element kodu kulturowego był tak mocno ugruntowany, że dążenia modernizacyjne, zmierzające do przyznania Żydom praw i obowiązków na równi z innymi obywatelami napotykały znaczny opór. Zob. E.A. Schmidl Żołnierze żydowscy w Austrii; B. Breysach Ze sobq, obok siebie, przeciwko sobie, s. 111-112.

11 D. Meghnagi L'espulsione degli Ebrei dalla Spagna: tra memoria e storia; Espulsionie exili, ed. D. Meghnagi, Armando Editore, Roma 1996, s. 7-26. W umiędzynarodowieniu tych reguł niezwykle znaczącą rolę odegrały zakony nauczające, zwłaszcza te, które wywodziły się z Hiszpanii.

12 J. Littell Łaskawe, przeł. M. Kamińska-Maurugeon, Wydawnictwo Literackie, Warszawa 2008.

13 J. Tokarska-Bakir 1939: Littell, www.dwutygodnik.com/artykul/415-1939-littell.html/ (16.08.2017). 
Poświadczenie ciągłości wskazanego przez Shulamit Volkov (antysemickiego) kodu kulturowego można łatwo znaleźć w literaturze; jednak natrafiając na te świadectwa, nie należy czynić z nich „incydentów drugiego rzędu”, czyli świadectwa osobistych i zreflektowanych przekonań autorów ${ }^{14}$. Raczej trzeba by zacząć je traktować - za Rosemary Radford Ruethers - jako symptomy formacji.Tak, jak z perspektywy literackiej przedstawił to Henryk Grynberg. W Memorbuchu jest cały rozdział15 porządkujący incydenty antyżydowskie w europejskich miastach, które odwiedza para bohaterów ${ }^{16}$ - od pierwszych wzmianek o żydowskiej gminie do Endlösung ${ }^{17}$.

Skądinąd taki punkt widzenia, akcentujący incydentalność jakiegoś zjawiska, jest nader wygodny, gdyż ostatecznie nawet zjawiska powtarzające się i w tej powtarzalności ujawniające strukturę właściwą rytuałowi można przedstawić jako izolowane, a tym samym zasadnie zwolnić się i od zauważenia tego rytualnego porządku, a nawet od ustalania (ewentualnych) między nimi relacji. Incydentami były więc i regularne wypędzenia Żydów z ziem chrześcijańskich; i rytualne „dysputy teologiczne”,których rezultat był zawsze a priori znany; i przymusowe konwersje $\mathrm{e}^{\mathbf{1 8}}$; i sądowe mordy rytualne z aryjskiego paragrafu ${ }^{19}$, i pogromy oraz konsekwentnie praktykowane „dyscyplinowanie”

14 Zwracałam na to uwagę w tekście Niewinna Europa albo przezroczyste zło. Antysemityzm w opus magnum Marcela Prousta; Filozofia w literaturze, literatura w filozofii, red. A. Iskra-Paczkowska, S. Gałkowski, M. Stanisz, Wydawnictwo URz, Rzeszów 2013, s. 181-190.

H. Grynberg Memorbuch, W.A.B., Warszawa 2000, r. Podróż poślubna, s. 234-255.

Adam Bromberg z żoną; Bromberg - wybitny polski wydawca, pomysłodawca i organizato edycji Wielkiej encyklopedii PWN; ofiara Marca'68, założyciel jednej z najbardziej prestiżowych oficyn literackich w Szwecji.

Por. także H. Grynberg Prawda nieartystyczna, Almapress-Czeladź, Katowice 1990, s. 39-41.

Ta forma opresji często bywa niesłusznie kojarzona tylko z Hiszpanią. Ale Hiszpania wyjątkiem nie była, ponieważ przymusowe "nawrócenia" były regularną praktyką w całej Europie Zachodniej - i wszędzie ci anusim (w ladino i iudesmo przymuszeni) byli podejrzewani o "nieszczerość", a zatem regularnie inwigilowani i oskarżani pod byle pretekstem. Ostatni Dom Katechumenów - miejsce, do którego oddawano żydowskie dzieci zgłoszone jako ochrzczone przez kogoś, kto miał po temu sposobność (praktyka prawnie dozwolona) zlikwidowano w Lombardii w 1870 roku. (D. Meghnagi L'espulsione degli Ebrei dalla Spana, s. 16.; por także Y. Eliach Non ricordare... non dimenticare..., Citta Nuova, Roma 1992, s. 27-29).

Zob. E. Janicka Mord rytualny z aryjskiego paragrafu. O ksiq̨żce Jana Tomasza Grossa "Strach. Antysemityzm w Polsce po wojnie. Historia moralnej zapaści”, "Kultura i Społeczeństwo" 2008 nr 2, s. 229-225. Janicka znalazła syntetyczną formułę, oddającą charakter tego elementu kodu kulturowego (wskazanego przez Volkov), jakim były procesy "o profanację hostii" czy "mord rytualny". Por. także moją uwagę: "sądowe morderstwo rytualne [...] procesy wytaczane Żydom 
Żydów przez pomniejsze akty przemocy, w których wyróżnić należy akty łączące przemoc fizyczną z przemocą symboliczną - takie jak profanowanie miejsc kultu oraz bezczeszczenie praktyk religijnych. Regularność takiej praktyki atomizacyjnej - pozwalającej na zajęcie bardzo dogodnej pozycji świadka, który patrząc, widzi wszystko oddzielnie $e^{20}$, sprzyja powstawaniu specyficznej aury wokół zjawisk, którym trwale przypisano status incydentów. Atmosfera staje się napięta zasadniczo przy wszystkich dyskusjach, dotyczących polskiego antysemityzmu, niezależnie od tego, czy tak nazwane zjawisko jest negowane, czy też piętnowane. A rzecz w tym, że dyskusja o zjawisku poza ten schemat uporczywie nie chce wyjść. Czyli nie tyle jest to dyskusja o zjawisku, ile o współczesnym wobec niego nastawieniu; i nie ma charakteru analitycznego, ale aksjologiczny. Ujawnienie nastawienia uczestników takiej debaty, jakkolwiek jest pożądane, nie może być traktowane jako równowartość zrozumienia przedmiotu debaty. Owszem, projektowanie na ten przedmiot współczesnych wymogów aksjologicznych, a co więcej, oczekiwanie powszechnej tych wymogów akceptacji i krytyka zarówno odmowy takiej akceptacji,jak i wstrzymania się z osądem, może przyczyniać się do budowania swoistej iluzji poznawczej. Przykładem tego procesu są zarówno prace krytycznych badaczy Zagłady, jak i ich recepcja. Jeśli te publikacje są systematycznie kontestowane, to bynajmniej nie dlatego, że będące ich podstawą badania są nierzetelne - takie zarzuty są nie do utrzymania, aczkolwiek mimo to są przyjmowane i powielane. Opór, sprawiający, że łatwiej zaakceptować niedające się utrzymać „kontrargumenty” niż - nazywane skandalem - źródła oraz hipotezy samych badaczy, jest generowany przez ten specyficzny tryb aksjologiczny, który wyraźnie rozmija się z - nierozpoznanym lub apriorycznie wykluczonym $z$ horyzontu refleksji - backgroundem odbiorców ${ }^{21}$. Dysonans poznawczy uruchamia mechanizmy obronne; im silniejszy dysonans, tym prostszy system obrony. Tak więc zaprzeczanie i przeniesienie zaskoczeniem być nie mogą: jeśli odbiorca reaguje na jakiś przekaz oburzeniem i od-

pod zarzutami «zabijania dzieci na macę» oraz «zatruwania studzien» [...] były elementem konstytutywnym dla usankcjonowania i zracjonalizowania antysemityzmu. [...] rytuałem, niezbędnym do potwierdzenia «żydowskiej winy», a przez to do gruntowania nawyku postrzegania Żydów jako «bardzo złych ludzi», w każdej chwili i w każdych okolicznościach popełniających zbrodnie", R. Kolarzowa Wprowadzenie do tradycji i myśli żydowskiej, Wydawnictwo URz, Rzeszów 2006, s. 359.

J. Tuwim Straszni mieszczanie, wiersze.bfcior.pl/julian-tuwim.php?show=mieszkancy (31.07.2017) 
rzuceniem go jako „rzeczy skandalicznej”, to przecież nie jest to kwestia obiektywnej kwalifikacji, ale jest to reakcja, wymagająca analizy. Bo ta skandaliczność, jako reakcja na budzący opór przekaz, z jakichś powodów się pojawia22. Skąd zatem dysonans? Antysemityzm nie jest przecież zjawiskiem specyficznie polskim, bo też polska kultura nie ma charakteru endemicznego. To jest - przypomnę - element kodu kulturowego, wkomponowany w strukturę kultury europejskiej, a poddany gruntownej rewizji i dekonstrukcji dopiero po Zagładzie. W Polsce, owszem, antysemityzm przyjął formy specyficzne, związane z osobliwą strukturą społeczno-ekonomiczną, której rezydua trwały do końca lat 30. XX wieku. I być może w tej specyfice trzeba by poszukać przyczyn siły tego oporu. Te osobliwości mają już swoją literaturę krytyczną, w której - rzecz znamienna - konsekwentnie występuje ta sama terra incognita ${ }^{\mathbf{2}}$, z którą mamy do czynienia w dekonstruowanej „historii naiwnej”. W analizach czynników kształtujących postawy społeczne, a zwłaszcza poczucie tożsamości wśród warstw podporządkowanych, pomijany jest jeden czynnik: wpływ duchowieństwa. Ściślej - wpływ praktyczny, wynikający z samego ulokowania stanu drugiego w sieci społecznej i z zadań, jakie z racji tego ulokowania stan ten miał wypełniać i wobec warstwy dominującej, i wobec warstw podporządkowanych. To jest bardzo rozległe zadanie badawcze - uporać się z zastanym spłaszczonym modelem, w którym zbiorowymi aktorami są „władza i społeczeństwo”, „szlachta i lud”, „lud i Żydzi” etc. Duchowieństwo, stan długo przecież osobny - ani tożsamy z władza, ani z ludem - uczestniczył w każdej z tych konfiguracji, mając wpływ (nieraz rozstrzygający, na poziomie metawładzy) na pozostałych aktorów. Ten wpływ można by zrekonstruować, przynajmniej częściowo, na podstawie zachowanych zbiorów kazań, materiałów dydaktycznych, a od końca XIX wieku także na podstawie publikacji prasowych. Takie cząstkowe badania, owszem, są prowadzone. Koncentrują się one jednak przede wszystkim wokół zagadnień „czysto polskich"24; zagadnienie udziału duchowieństwa w kształtowaniu

22 P. Dobrosielski Spory o Grossa. Polskie problemy z pamięcią o Żydach, Wydawnictwo IBL PAN, Warszawa 2017; M. Nowicka-Franczak Niechciana debata; Spór o książki Jana Tomasza Grossa, Wydawnictwo Akademickie Sedno, Warszawa 2017.

23 Dotyczy to także prac, które należy uznać za bardzo znaczące, m.in. D. Beauvois Trójkąt ukraiński. Szlachta, carat i lud na Wołyniu, Podolu i Kijowszczyźnie 1793-1914, przeł. K. Rutkowski, Wydawnictwo UMCS, Lublin 2005; J. Sowa Fantomowe ciało króla. Peryferyjne zmagania z nowoczesną formą, Universitas, Kraków 2012; A. Leder Prześniona rewolucja. Ćwiczenie z logiki historycznej, Wydawnictwo Krytyki Politycznej, Warszawa 2014.

Stwierdzenie to wynika z kwerendy przeprowadzonej na potrzeby tego tekstu. 
antysemickiego kodu kulturowego poruszane jest sporadycznie. Najobszerniejszym opracowaniem, dotyczącym lat 1933-1939 jest monografia Rolanda Modrasa $^{25}$. Badania bardziej szczegółowe, poświęcone najczęściej wybranemu tytułowi z wydawnictw kościelnych, są i sporadyczne, i podporządkowane schematowi „atnyjudaizm czy antysemityzm" ${ }^{26}$. Takie preferencje badaczy wstępnie zdają się potwierdzać intuicję, że zarówno samo zagadnienie występowania antysemickiego kodu kulturowego, jak środki i sposoby reprodukowania i wzmacniania go mogą mieć bardzo ścisły związek z całym zespołem procesów związanych z konstruowaniem tożsamości narodowej. Nie przeczy tej intuicji istnienie „polskiej szkoły socjologii narodu”, głoszącej odrębną od zachodniej drogę konstruowania polskiej tożsamości narodowej ${ }^{27}$. Według referującego to złożone zagadnienie Pawła Kubickiego droga zachodnia prowadziłaby „z góry na dół” - „od kulturotwórczych elit posiadających monopol na reprodukcję kultury do szerokich mas. Natomiast w przypadku Europy Środkowej, z uwagi na niezwykle skomplikowaną sytuację polityczną, etniczną, religijną [...] proces ten przebiegał w odwrotnym kierunku: «z dołu do góry»"28. Otóż taka koncepcja jest kontrempiryczna; o tym, że żadna kulturowa transmisja „z dołu do góry”, przyczyniająca się do skonstruowania współczesnej tożsamości narodowej, nie istniała i nie była możliwa, świadczą źródła, do których zaliczyć należy wszystkie programy budzenia świadomości narodowej czy wręcz unarodowienia ${ }^{29}$. Same określenia programowe jasno wykładają stanowisko twórców: trzeba oddziaływać na obiekty pasywne (uśpione), poddając je stosownej obróbce ${ }^{30}$. Określenia te ujawniają też

25 R. Modras Kościół katolicki i antysemityzm w Polsce w latach 1933-1939, przeł. W. Turopolski, przedm. S. Obirek, Homini, Kraków 2004.

26 Przykładem: A. Meller Antysemityzm czy antyjudaizm na łamach miesięcznika "Pro Christo" (1924-1939), "Historia i Polityka” 2009 nr 1 (8); http://dx.doi.org/10.12775/HiP.2009.001 (05.08.2017).

27 P. Kubicki Miasto wsieciznaczeń. Kraków i jego tożsamość, Księgarnia Akademicka, Kraków 2010, s. 53-54.

Tamże, s. 53.

29 Pojęcie unarodowienia weszło do języka publicystyki społecznej i jest nadal używane np. w omówieniach polityki wobec mniejszości w II RP. Najnowszy przykład: Polska dqż̇yła do unarodowienia oraz nawrócenia tej ludności na katolicyzm. M. Kargol Naoczny świadek, „Przegląd” nr 28 (914) $10-16.07 .2017$.

O tym, jaki był stan świadomości „dołów" $\mathrm{i}$ jakie były reperkusje unarodowiania warstw podporządkowanych, pisałam w "Zamawianie” Realnego. Konstruowanie tożsamości fantazmatycznej "narodu politycznego", ,Teksty Drugie" 2015 nr 1, s. 84-95. 
pozycję podmiotową twórców takich projektów: zajmują oni pozycję sprawczą - są projektantami, mają być wykonawcami i nadzorcami prawidłowości operacji. To nie były programy tworzone „z dołu”, ale koncepty kulturotwórczych elit, obliczone na „wychowanie mas”. Różnica między konstruowaniem tożsamości narodowej nie tkwi w odmiennym biegu drogi, ale w instytucjach, którym przyznano rolę decydującą, i w arsenale środków. No i w tej osobliwości, którą najchętniej się pomija: że w gruncie rzeczy było to nie konstruowanie tożsamości, ale jej restrukturyzacja, polegająca na włączeniu w pojęcie wspólnoty narodowej tych, którzy dotąd byli z niej oficjalnie wykluczeni wskutek uznawania przez elity kulturotwórcze różnicy jakościowej między warstwą własną a warstwami podporządkowanymi. Na ziemiach polskich instytucjami zarządzającymi i kontrolującymi budzenie świadomości narodowej (resp. unarodowienie) były te same instytucje, które wcześniej reprodukowały i nadzorowały wykluczenie: dwór i kościół. To dlatego tak istotna jest wiedza o praktyce transmisji kulturowej nowego programu i o treściach, które były reprodukowane i transmitowane. Najmniej użyteczne dla poszerzenia tej wiedzy są dokumenty oficjalne, a powód tego jest prozaiczny: dla „obiektów”, poddawanych zabiegowi „budzenia świadomości narodowej” ich treść przeważnie pozostawała niedostępna.Treści, podawanych wprost, należy szukać gdzie indziej. Przede wszystkim w prasie wysokonakładowej; nie bez powodu "Mały Dziennik" był nie tylko gazetą o najwyższym nakładzie, ale też najtańszą. Nawet uwzględniając wysoki, choć regionalnie ogromnie zróżnicowany stopień analfabetyzmu, treści, kolportowane w kilkusettysięcznym nakładzie należy traktować jako treści powszechnie dostępne. Tym bardziej że należy uwzględnić ich wpływ pośredni, docierający także do tych, którzy nie umieli czytać; nawet tam, gdzie analfabeci byli większością. Zawartość konfesyjnej prasy codziennej, i periodyków - takich jak dwutygodnik „Rycerz Niepokalanej” czy miesięcznik „Pro Christo” - była w kwestii żydowskiej oraz w konstruowaniu wzorca Polak - katolik antysemita bardzo jednorodna ${ }^{31}$. W analizowanych przez Modrasa przykładach doskonale widoczna jest ciągłość narracji antyżydowskiej: narracja „antyjudaistyczna" przechodzi w „antysemicką" tak płynnie i naturalnie, że rozgraniczenie ich wydaje się zabiegiem sztucznym. Co zaś najważniejsze, zawartość ta była aprobowana przez system podwójnej, kościelnej i państwowej, cenzury. Tę oczywistość zwykle się pomija, a wydaje się ona jedną z kluczowych danych, pozwalających zrozumieć siłę oddziaływania formacyjnego tych przekazów. Miały one status niebu-

Zob. R. Modras Kościół katolicki i antysemityzm w Polsce, s. 155-162, 195-216. 
dzących zastrzeżeń ani władzy świeckiej, ani duchownej i w takim charakterze podlegały rozpowszechnianiu. Drugą, równie często ignorowaną okolicznością, jest charakter podległości konfesyjnej. Swoboda wyznania, a zwłaszcza swoboda praktyk religijnych, co najmniej do końca II Rzeczypospolitej była przywilejem warstwy elitarnej. W realiach warstw podporządkowanych istniała presja zarówno instytucjonalna, jak i społeczna, obligująca do uczestnictwa w praktykach wyznaniowych i do poddawania się kontroli zarówno w zakresie sposobu życia, jak i poprawności przyswajania podawanych treści. Zważywszy że według Rocznika statystycznego z 1921 roku było w kraju 33,1\% analfabetów, zaś odsetek ludności zamieszkującej w miastach powyżej 25 tys. mieszkańców wynosił 13\%, ale w niemal połowie kraju odsetek analfabetów sięgał 70\% (wśród kobiet strefowo zbliżał się do 90\%), a mieszkańców większych miast było mniej niż 5\% ${ }^{32}$, można przypuszczać, że dla tak wielkiej, całkowicie niewykształconej grupy ludności treści rozpowszechniane w ramach oddziaływania formacyjnego podstawowych jednostek administracji kościelnej były najważniejszymi, jeśli nie wręcz jedynymi dostępnymi treściami intelektualnymi. I to treściami, od których realnie nie można było uchylić się; pod tym względem nie istniała żadna „autonomia ludu”. Toteż „lud”, praktycznie nadal osadzony między panem, wójtem i plebanem, przyswajał te treści tak samo, jak wszystkie inne, które miał podane do wierzenia: jako coś, co jest samą oczywistością i należy do nienaruszalnego porządku. Sama możliwość zdystansowania się od tej części kodu kulturowego, nawet ex post, wydaje się problematyczna: wiąże się bowiem ze zdystansowaniem od najbardziej autorytatywnego źródła, postrzeganego jako legitymizacja własnej tożsamości.

Czynnikiem zyskującym w II RP znaczenie formacyjne stało się obligatoryjne szkolnictwo powszechne. Ten wątek wymaga gruntownego przebadania nie tylko z uwagi na założenia pedagogiczne, formułowane expressis verbis czy równie jawnie dookreślany charakter ideologiczny, ale też z uwzględnieniem tego, co Basil Bernstein nazwał hidden curriculum $^{33}$. Poleganie na samych aktach normatywnych i dedukowanie na ich podstawie charakteru powszechnego kształcenia elementarnego byłoby przykładem gilmanowskiego „badania powierzchni retoryki". Niemniej sama ta powierzchnia ujawnić może znaczące napięcia i rysy. Urszula Wróblewska zwróciła uwagę na swoistą w II RP dia-

32 Szczegółowe dane zob. A. Notkowski Polska prasa prowincjonalna Drugiej Rzeczypospolitej (1918-1939), PWN, Warszawa-Łódź 1982, s. 212-213, 231-232.

33 B. Bernstein Codes, modalities and the process of cultural reproduction: A model, "Language in Society" 1981 Vol. 10, No. 3, s. 327-363. 
lektykę między „wychowaniem narodowym” i„wychowaniem państwowym”. $\mathrm{Z}$ analizy autorki wynika jednak, że dialektyka ta była pozorna - w 1932 roku reforma Jędrzejewicza nie unieważniła wychowania narodowego ani idei polonizacyjnej, silnie akcentującej identyczność lojalności obywatelskiej i asymilacji. Nie zniosła też starszej Ustawy Grabskiego, wprost negującej nieplemienną koncepcję narodu. Znamienne, że sama autorka najmniej miejsca poświęca sytuacji zarówno żydowskiego szkolnictwa elementarnego, jak i pozycji żydowskich uczniów w państwowych szkołach powszechnych - zaznacza tylko, że polityka oświatowa wobec mniejszości była zróżnicowana i zależała od względów bezpieczeństwa ${ }^{35}$.

Aby ustalić, w jakim zakresie szkolnictwo elementarne w II RP reprodukowało istniejące wzorce kulturowe, trzeba by przeprowadzić analizy źródeł (pamiętniki nauczycieli i uczniów, sprawozdania oświatowe) i opracowań cząstkowych (kwerendy etnograficzne, publikacje poświęcone szkolnictwu). Nie można także pominąć, w jakim zakresie szkoła elementarna była nośnikiem autorytetu, jak jej autorytatywność była legitymizowana i na ile był on projekcją autorytetu pana i plebana. Na podstawie fragmentarycznych, odnoszących się do opisów społeczności lokalnych można wysuwać przypuszczenia, że szkoła elementarna na wsi sama źródłem autorytetu nie była; obowiązek szkolny ustępował powinnościom gospodarczym³ ${ }^{36}$. Jej autorytet - jeśli był - wynikał więc z zapośredniczenia w autorytecie państwa i Kościoła. Analizując politykę oświatową, związaną z obowiązkowym nauczaniem elementarnym, trzeba by zatem uwzględnić co najmniej trzy czynniki: a) formalne scalenie „oświecenia publicznego” oraz „wyznań” (Ministerstwo Wyznań i Oświecenia Publicznego); b) miejsce „walorów religijno-moralnych” w projekcie „wychowania obywatelsko-moralnego”; c) praktyki katechetyczne i ich rolę w reprodukcji wzorców kulturowych. Można by w tych badania skorzystać z propozycji G.R. Zamanzadeha, F. Nateghiego i Mohammada Seifiego, którzy opracowali schemat badania „treści niebezpośrednich”, przekazywanych w ramach szkolnictwa wyznaniowego ${ }^{37}$. Znając dominujący

U. Wróblewska Polityka oświatowa państwa polskiego wobec mniejszości narodowych, grup etnicznych i wyznaniowych zamieszkujących Kresy Wschodnie w II RP, „Nauka” 2011 nr 2, s. 109-124.

Tamże, s. 117, 123.

Zob. J. Fierich Opisanie ziemi ropczyckiej, Nakładem autora Drukarnia W.L. Anczyca i S-ki, Kraków 1936.

G.R. Zamanzadeh, F. Nateghi. M. Seifi Claryfing the Effective Factors of Hidden Curriculum of Schools on Establishment of the Aims of Religious Education of Elementary Schools Students 
w II RP ton dyskursu „o Żydach” - esencjalnie przedstawił go Henryk Grynberg $^{38}$ - można wstępnie założyć, że ton ten wybrzmiewał w szkole zarówno bezpośrednio, w formie podręczników i treści dydaktycznych, jak i organizował "treści niebezpośrednie”, choćby przez sposób komunikacji uczniów między sobą oraz nauczycieli do uczniów polskich i uczniów żydowskich (to jest istotny czynnik, tworzący środowisko społeczne) ${ }^{39}$.

Wskazane tu punkty (b) i (c) skłonna byłabym uznać za kluczowe, dlatego że niezależnie od wszystkich zmian, w tym politycznych i prawnych, zachowywały ciągłość przekazu ${ }^{40}$. Katecheza była - do 1963 roku - stałym punktem edukacji powszechnej; w odróżnieniu od świeckich elementów nauczania, zachowywała trwały i silny związek z życiem pozaszkolnym. Niezależnie od tego, w jakim stopniu obowiązek szkolny był realizowany, treści, należące do katechezy były transmitowane systematycznie, a przynależność wyznaniowa była (jeszcze w drugiej połowie lat 40. XX wieku) istotnym czynnikiem formalnym, określającym tożsamość jednostki. Wyraziście ujawnia to materiał dokumentalny przedstawiony przez Joannę Tokarską-Bakir w studium pogromu kieleckiego: pracownicy Służby Bezpieczeństwa, Milicji Obywatelskiej i cywilni pogromszczycy, niezależnie od tego, jakim wykształceniem się legitymowali, byli określeni „z wyznania"41; byłby to zatem pierwszorzędny czynnik, kształtujący habitus w samej rzeczy narodowy, ponad podziałami klasowymi, ponieważ jego istotną cechą, oprócz ciągłości, była także spójność przekazu, zwłaszcza tego adresowanego do najszerszego grona odbiorców ${ }^{42}$.

(Case Study of Ahvaz City), "Modern Applied Science”, Vol. 11, No 1; 2017 (online, October 2016), http://dx.doi.org./10.5539/mas.v11n1p124 (14.03.2018)

38 H. Grynberg Historia polsko- żydowska, w: Monolog polsko-żydowski, Czarne, Wołowiec 2003, s. 7-41.

Np. M. Grynberg OcalenizXX wieku. Po nas niktjużnie opowie, najwyżej ktoś przeczyta..., Warszawa 2012, s. 331-338. Zob. także J. Tokarska-Bakir Pod klątwą. Społeczny portret pogromu kieleckiego, Czarna Owca, Warszawa 2018, t. 1, s. 114-133.

40 J. Leociak Młyny Boże. Zapiski o Kościele iZagładzie, Czarne, Wołowiec, 2018, s. 25-33.

41 J. Tokarska-Bakir Pod klątwq..., t. 2, Dokumenty, s. 283-582.

42 Por. np.: ks. A. Quinet, wizytator nauki religii w diecezji paryskiej Dla najmniejszych dwadzieścia lekcyj katechizmu metodq czynną, Wyd. Księży Jezuitów, Kraków 1933 (zwł. rozdz. XIII i XIX); Ks. J. Pichler Katechezy katolickie dla szkółludowych, t. 1., Nakładem Zgromadzenia Ks. Ks. Misjonarzy, Kraków 1931; ks. J. Grabowski Rekolekcje wielkopostne. Zbiór kazań rekolekcyjnych dla ludu polskiego, Nakładem autora Drukarnia "Nowość”, Kielce 1936; ks. J. Małysiak Z.P.P Kazania radjowe, Nakł. Księży Przemienienia Pańskiego, Kielce 1935. 
Ciągłość przekazu jest nadal zachowywana, jak zwraca uwagę Jacek Leociak, nawet personalnie ${ }^{43}$. Ignorowanie badawcze przekazów tradycjonalnych nie wpływa na ich nośność. Ukazują się publikacje, warsztatowo bardzo sprawne, które - niepoddawane krytycznej analizie - mają spore znaczenie formacyjne, właśnie dlatego że bez przeszkód wzmacniają wzorzec tradycyjny ${ }^{44}$. Zakresu ich oddziaływania trudno nie zauważyć w przestrzeni publicznej. Także edukacyjnej, gdzie przekaz religijny nie podlega nadzorowi szkolnemu. Toteż bez przeszkód mogą ukazywać się podręczniki takie jak Kto spożywa moje ciało ma życie (dla klas III szkoły podstawowej) ${ }^{45}$. O nich trudno już byłoby utrzymywać, że „są to publikacje niszowe”; instytucjonalnie nadal podtrzymują do niedawna wspólny dla kultury zachodniej pewnik, że Żydzi to bardzo źli ludzie ${ }^{46}$ - w tej samej intencji: wykazania, że antysemityzm jest "reakcją obiektywną", a antysemickie wzorce ani nie wymagają usprawiedliwienia, ani nie zaburzają poczucia niewinności.

J. Leociak Młyny boże, s. 56-64.

Np. T. Gabiś Religia Holocaustu, cz. 1, "Stańczyk” 1996 nr 2 (29), s. 9-43; cz. 2, "Stańczyk” 1997 nr 1 (30), s. 16-37; H. Hajducki „Religia Holocaustu” a dialog katolicko-żydowski, cz. I - V; cz. IV: Dogmat o winie i odpowiedzialności Kościoła za Holocaust, "Zawsze wierni” $2002 \mathrm{nr} 2$ (45) www. piusx.org.pl/zawsze_wierni/artykul/486 (16.03.2018).

G. Michalczyk Krzyżówka "Żydzi wydali Jezusa”, www.wiez.com.pl/2016/11/19/krzyzowka-zydzi-wydali-jezusa (16.03.2018). W recenzji autor zwrócił też uwagę na występujące w polskim katolicyzmie osobliwości liturgiczne; warto też zwrócić uwagę na komentarz czytelniczki z linkiem do katechezy na oficjalnej stronie Konferencji Episkopatu Polski.

46 F. Mussner Traktat o Żydach, przeł. I. Kruszewska, Wydawnictwo ATK, Warszawa 1997, s. 16. Na s. 15-16 Mussner zwięźle opisał proces warunkowania prowadzącego do tego pewnika. 


\section{Abstract}

\section{Romana Kolarzowa}

UNIWERSYTET RZESZOWSKI

Anti-Semitism as a Constitutive Element of the Polish Habitus

Kolarzowa argues that Polish anti-Semitism is a continuous phenomenon that cannot be divided into "anti-Judaism" and "anti-Semitism". Using the triangulation method, she indicates that all European anti-Semitism is embedded in traditional theological narratives and the resulting social options. She also discusses the reasons behind this continuity of Polish anti-Semitism, including the specificity of Poland's social structure and the nobility's objectives in instrumentalizing anti-Semitic discourses. AntiSemintism was supposed to provide an inclusive option to the lower-ranking groups, while the term 'nation' was reserved for the nobility. This explains the prominent role of clergy in this narrative: the clergy was the only group capable of effectively shaping a collective identity of underprivileged social strata and presenting Judaism as an "antimodern," so that anti-Semitism was associated with the identity of the modern nation.

\section{Keywords}

anti-Semitism, religious hatred, cultural patterns, collective identity 